\section{HIGH BLOOD PRESSURE IN THE ELDERLY}

\author{
BY
}

HUGO DROLLER, M.D., M.R.C.P.

JOHN PEMBERTON, M.D., M.R.C.P.

CISSIE ROSEMAN, B.Sc.

(From the Department of Social and Industrial Medicine, University of Sheffield)

AND

J. L. A. GROUT, F.R.C.S.Ed., F.F.R. Consultant Radiologist to the United Sheffield Hospitals

The observations which follow were derived from the medical examinations of 476 elderly people living at home in Sheffield and from the radiological examination of 332 of them. The age- and-sex distribution is shown in Table I. This paper deals only with observations on the blood pressure, the main report will be published elsewhere.

TABLE I.-Age and Sex

\begin{tabular}{|c|c|c|c|c|c|}
\hline Years: & $60-$ & $65-$ & 70 & $75-$ & All Ages \\
\hline No. of females & 44 & 105 & 75 & 60 & 284 \\
\hline $\begin{array}{lll}\text { group } & \cdots & \ldots \\
\% \text { of males in each age group }\end{array}$ & 16 & $\begin{array}{l}37 \\
39 \\
20\end{array}$ & $\begin{array}{l}26 \\
80 \\
42\end{array}$ & $\begin{array}{l}21 \\
73 \\
38\end{array}$ & 192 \\
\hline
\end{tabular}

Series of cases of hypertension as studied in hospital or the doctor's surgery inevitably consist largely of patients with symptoms which have been rightly or wrongly attributed to the raised blood pressure. The present survey included a good many subjects with hypertension without symptoms who considered themselves fit, and, conversely, some without hypertension but with symptoms often ascribed to it. It therefore provided an opportunity of comparing the incidence of certain symptoms and signs commonly associated with hypertension in thọse with and without hypertension.

The conditions studied in relation to hypertension were vertigo, tinnitus, angina of effort, clinical arteriosclerosis, radiological enlargement of the heart, and the subject's well-being and activity. Data about these conditions were systematically collected in each case. No cases of malignant hypertension or chronic nephritis were found, possibly owing to the age of the subjects, and all the cases of hypertension were regarded as belonging to the benign group. It should be emphasized that only elderly subjects were studied, and the conclusions reached may not apply to hypertension in younger persons.

\section{The Sample}

In 1948 a social survey had been carried out by the Sheffield Council of Social Service on a 1:30 sample of all Sheffield old people of pensionable age - that is, women over 60 and men over 65 (Greenlees and Adams, 1950). The sample had been selected by a random procedure from the food office register. The group of elderly people used in the medical survey was derived from this sample and included all those living alone or alone with spouse who could be traced, and who agreed to be examined. Those living alone or alone with spouse were chosen to facilitate a dietary survey which was carried out at the same time. Of 672 possible subjects, 196 were not available when the medical survey came to be done; 36 were no longer living alone or alone with spouse; 18 had left Sheffield or could not be traced; and in 142 cases consent for the examination was withheld. As two years had elapsed between the two surveys, the youngest women in the medical survey were 62 and the youngest men 67 .

In the tables the conventional quinquennial age groups have been retained, although this means that the youngest age group in both sexes is smaller than it should be. The sample included all social classes, and we believe was reasonably representative of elderly people living independently at home. Information about frequency of medical attention, obtained at the earner social survey, showed that those who refused the clinical examination did not differ significantly from those who agreed to it in this respect. This suggests that those who refused did so mainly on other grounds than health. There was a higher proportion of women and of representatives of the higher income groups amongst the refusals. One physician (H. D.) carried out $94 \%$ of the medical examinations.

Method.-The blood pressures were taken with a standard mercury sphygmomanometer with the subject in the reclining position after having rested for five minutes or longer. For the study of individual cases a single estimate is unsatisfactory, but in comparing the mean blood pressures of groups the single measurement is less open to objection.

Age and Sex

The distribution of the blood pressures by broad groups is shown in Table II. It will be noted that hypertension

TABLE II.-Percentage Distribution of Blood-pressure Readings

\begin{tabular}{|c|c|c|c|c|}
\hline & \multicolumn{3}{|c|}{ Systolic, $\mathrm{mm} . \mathrm{Hg}$} \\
\hline & & $100-159$ & $160-189$ & 190 \\
\hline \multirow[t]{3}{*}{187 men } & $\begin{array}{ll} & \cdots\end{array}$ & $\begin{array}{l}42.8 \\
22.9\end{array}$ & $\begin{array}{l}38 \cdot 5 \\
48 \cdot 3\end{array}$ & $\begin{array}{l}18.7 \\
28 \cdot 8\end{array}$ \\
\hline & & \multicolumn{3}{|c|}{ Diastolic, $\mathrm{mm} . \mathrm{Hg}$} \\
\hline & & \multicolumn{2}{|l|}{$0-99$} & 100 \\
\hline $\begin{array}{l}187 \text { men } \\
271 \text { women }\end{array}$ & $\begin{array}{ll} & \cdots \\
& \end{array}$ & $\begin{array}{l}71 \cdot 7 \\
52 \cdot 4\end{array}$ & & $\begin{array}{l}28.3 \\
47.6\end{array}$ \\
\hline
\end{tabular}

was commoner in the women than in the men. Most other authors have found this-for example, Master et al. (1943) and Boas (1950).

Fifty-seven per cent. of the men and $77 \%$ of the women had systolic pressures of $160 \mathrm{~mm}$. $\mathrm{Hg}$ or over, and $28 \%$ of the men and $48 \%$ of the women had diastolic pressures of $100 \mathrm{~mm}$. Hg or more. Howell (1950) found that threequarters of the Chelsea Pensioners whom he studied had systolic blood pressures of $160 \mathrm{~mm}$. $\mathrm{Hg}$ or more.

TABle III.-Mean Blood Pressure at Different Ages

\begin{tabular}{|c|c|c|c|c|}
\hline Years: & $60-$ & $65-$ & $70-$ & $75-$ \\
\hline $\begin{array}{l}\text { No. of men } \\
\text { Mean systolic B.P. } \\
\text { No. of women } \\
\text { Mean systolic B.P. }\end{array}$ & $\begin{array}{c}41 \\
172 \cdot 8\end{array}$ & $\begin{array}{l}39 \\
157 \cdot 3 \\
100 \\
178 \cdot 2\end{array}$ & $\begin{array}{l}77 \\
166 \cdot 8 \\
72 \\
178 \cdot 0\end{array}$ & $\begin{array}{l}71 \\
172 \cdot 8 \\
58 \\
186 \cdot 0\end{array}$ \\
\hline $\begin{array}{l}\text { No. of men } \\
\text { Mean diastolic B.P. } \\
\text { No. of women } \\
\text { Mean diastolic B.P. }\end{array}$ & $\begin{array}{l}41 \\
98.2\end{array}$ & $\begin{array}{c}39 \\
89 \cdot 9 \\
100 \\
99 \cdot 5\end{array}$ & $\begin{array}{l}77 \\
92 \cdot 5 \\
72 \\
98 \cdot 5\end{array}$ & $\begin{array}{c}71 \\
91 \cdot 8 \\
58 \\
100 \cdot 0\end{array}$ \\
\hline
\end{tabular}

Table III shows the mean systolic and diastolic blood pressures by sex and age. There was a trend towârds slightly higher mean systolic blood pressures with advancing age, but analysis of variance showed that the difference in levels between the age groups was not significant.

To obtain a measure of the general trend of systolic blood pressures with age in the ungrouped data, the correlation coefficients were calculated from the individual pairs of values. Neither of these coefficients $(r=0.095,0.122$, for men and women respectively) was significant.

There was a wide range in the blood pressures. Possibly if there had been a larger number of observations the trend 
between the age groups might have been shown to be significant. With regard to diastolic blood pressure there was, no trend with age.

While there seems to be agreement that the diastolic blood pressure does not normally rise with age, most authorsfor example, Blackford et al. (1930), Howell (1942), Russek (1943), and Master et al. (1943)-have found higher mean systolic pressures or a higher incidence of high systolic pressures with advancing age after the age of 40 .

\section{Hypertension and Vertigo}

Vertigo is a common and disabling symptom in the elderly which is often attributed to hypertension. It is commoner in women than in men (Sheldon, 1948). On inquiry we found that $29 \%$ of the women and $14 \%$ of the men complained of frequent or continuous vertigo. The mean systolic and diastolic blood pressures in those with no vertigo. occasional, and frequent or continuous vertigo are shown in Table IV. It shows that there was no relation between the presence of vertigo and the height of the systolic or diastolic blood pressure.

TABLE IV.-Vertigo and Blood Pressure

\begin{tabular}{|c|c|c|c|c|}
\hline & & \multicolumn{3}{|c|}{ Vertigo } \\
\hline & & None & Occasional & $\begin{array}{l}\text { Frequent or } \\
\text { Continuous }\end{array}$ \\
\hline $\begin{array}{l}\text { No. of men } \\
\text { Mean systo'ic B.P. } \\
\text { No. of women } \\
\text { Mean systolic B.P. }\end{array}$ & $\begin{array}{l}\cdots \\
\cdots \\
\cdots\end{array}$ & $\begin{array}{l}87 \\
166 \cdot 6 \\
103 \\
178 \cdot 0\end{array}$ & $\begin{array}{c}74 \\
169 \cdot) \\
87 \\
177 \cdot 4\end{array}$ & $\begin{array}{c}25 \\
165 \cdot 8 \\
81 \\
182 \cdot 0\end{array}$ \\
\hline $\begin{array}{l}\text { No. of men } \\
\text { Mean diasto'ic B.P. } \\
\text { No. of women } \\
\text { Mean diastolic B.P. }\end{array}$ & $\begin{array}{l}\cdots \\
\cdots \\
\cdots\end{array}$ & $\begin{array}{c}87 \\
91 \cdot 0 \\
103 \\
99 \cdot 0\end{array}$ & $\begin{array}{l}74 \\
92 \cdot 2 \\
87 \\
99 \cdot 1\end{array}$ & $\begin{array}{l}25 \\
92 \cdot 6 \\
81 \\
93 \cdot 3\end{array}$ \\
\hline
\end{tabular}

\section{Hypertension and Tinnitus}

Tinnitus in the elderly, like vertigo, is not infrequently attributed to a high blood pressure. Nine per cent. of the men and $10 \%$ of the women complained of having tinnitus continuously. Analysis of variance showed that there was no significant difference between the blood-pressure levels in those with continuous, occasional, or no tinnitus (Table V).

TABLE V.-Tinnitus and Blood Pressure

\begin{tabular}{|c|c|c|c|}
\hline & \multicolumn{3}{|c|}{ Tinnitus } \\
\hline & None & Occasional & Continuous \\
\hline $\begin{array}{ll}\begin{array}{l}\text { No. of men } \\
\text { Mean systo'ic B.P. }\end{array} & \ldots \\
\text { No. of women } \\
\text { Mean systolic B.P. } & \ldots \\
\end{array}$ & $\begin{array}{l}115 \\
167.2 \\
163 \\
179.2\end{array}$ & $\begin{array}{c}56 \\
163 \cdot 2 \\
77 \\
180 \cdot 6\end{array}$ & $\begin{array}{c}16 \\
180 \cdot 0 \\
28 \\
168.6\end{array}$ \\
\hline $\begin{array}{lll}\text { No. of men } & & \\
\text { Mean diastolic B.P. } & \cdots \\
\text { No. of women } & \ldots \\
\text { Mean diastolic B.P. } & \ldots\end{array}$ & $\begin{array}{l}115 \\
91 \cdot 6 \\
163 \\
99.5\end{array}$ & $\begin{array}{l}56 \\
91 \cdot 4 \\
77 \\
98 \cdot 8\end{array}$ & $\begin{array}{l}16 \\
93 \cdot 3 \\
28 \\
97 \cdot 1\end{array}$ \\
\hline
\end{tabular}

\section{Hypertension and Angina of Effort}

Hypertension and angina of effort are often found together in elderly people, and some authors-for example, Bell and Clawson (1928)-are of the opinion that coronary

TABLE VI.-Angina of Effort and Blood Pressure

\begin{tabular}{|c|c|c|c|c|c|}
\hline & & \multicolumn{2}{|c|}{ Angina } & \multicolumn{2}{|c|}{ Statistical Significance } \\
\hline & & Absent & Present & $\begin{array}{c}\text { S.E. of } \\
\text { Difference }\end{array}$ & $\mathrm{t}$ \\
\hline $\begin{array}{l}\text { No. of men } \\
\text { Mean systolic B.P. }\end{array}$ & $\begin{array}{l}\cdots \\
\cdots\end{array}$ & $\begin{array}{l}129 \\
164 \cdot 0\end{array}$ & $\begin{array}{c}51 \\
171.0\end{array}$ & $5 \cdot 09$ & $\begin{array}{l}\text { Not sig. on } \\
5 \% \text { level }\end{array}$ \\
\hline $\begin{array}{l}\text { No. of women } \\
\text { Mean systolic B.P. }\end{array}$ & $\begin{array}{l}\cdots \\
\cdots\end{array}$ & $\begin{array}{l}186 \\
177 \cdot 0\end{array}$ & $\begin{array}{c}74 \\
183 \cdot 0\end{array}$ & $4 \cdot 54$ & $\begin{array}{c}\text { Not sig. on } \\
5 \% \text { level }\end{array}$ \\
\hline $\begin{array}{l}\text { No. of men } \\
\text { Mean diastolic B.P. }\end{array}$ & $\therefore$ & $\begin{array}{l}129 \\
91 \cdot 9\end{array}$ & $\begin{array}{l}51 \\
94.0\end{array}$ & $2 \cdot 9$ & $\begin{array}{c}\text { Not sig. on } \\
5 \% \text { level }\end{array}$ \\
\hline $\begin{array}{l}\text { No. of women } \\
\text { Mean diastolic B.P. }\end{array}$ & 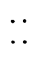 & $\begin{array}{l}186 \\
98 \cdot 0\end{array}$ & $\begin{array}{c}74 \\
1 \mathrm{CO} \cdot 0\end{array}$ & $2 \cdot 2$ & $\begin{array}{l}\text { Not sig. on } \\
5 \% \text { level }\end{array}$ \\
\hline
\end{tabular}

sclerosis is more frequent in hypertensive than in nonhypertensive persons. Of our subjects, $69 \%$ had systolic blood pressures of $160 \mathrm{~mm}$. or above, and $30 \%$ of these complained of various degrees of angina of effort, compared with $28 \%$ in the whole sample. Table VI shows that the mean systolic and diastolic blood pressures in both men and women were somewhat higher in those with angina, but the differences were not statistically significant.

\section{Hypertension and Clinical Arteriosclerosis}

It is difficult, if not impossible, to decide on the basis of clinical examination of the arteries whether the intimal or the medial coats are predominantly affected by degenerative processes. Our observations were based on palpation of the radial, brachial, and dorsalis pedis arteries and on ophthalmoscopic examination of the retinal arteries. On the basis of these observations the subject was classified as having marked, moderate, or no arteriosclerosis. The number and percentage of subjects falling in these groups by sex and age are shown in Table VII. . It will be seen that

TABLE VII.-Grades of Clinical Arteriosclerosis by Age and Sex

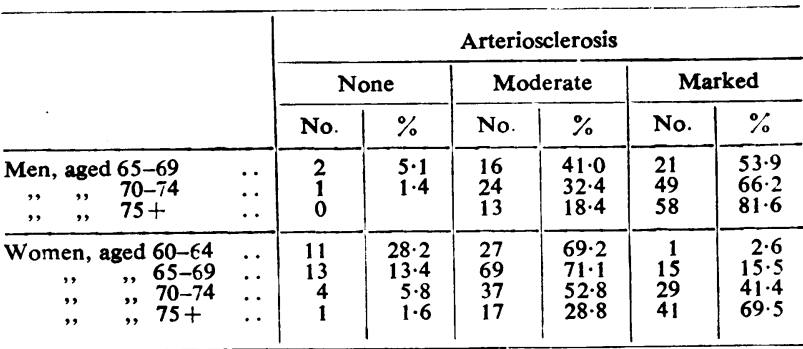

$x^{3}$ for increase of marked arteriosclerosis with age was highly significan in both sexes.

the incidence of marked arteriosclerosis in each age group was much higher in the men than in the women. The incidence increased significantly with age in both sexes.

The mean systolic and diastolic blood pressures were calculated in the three different grades of arteriosclerosis (Table VIII). There was no significant difference between the mean

TABLE VIII.-Arteriosclerosis and Blood Pressure

\begin{tabular}{|c|c|c|c|c|}
\hline & & \multicolumn{3}{|c|}{ Arteriosclerosis } \\
\hline & & None & Moderate & Marked \\
\hline $\begin{array}{l}\text { No. of men } \\
\text { Mean systolic B.P. } \\
\text { No. of women } \\
\text { Mean systolic B.P. }\end{array}$ & $\begin{array}{l}\ddot{*} \\
\ddot{*} \\
\cdots\end{array}$ & $\begin{array}{c}3 \\
(151 \cdot 6) \\
29 \\
169 \cdot 2\end{array}$ & $\begin{array}{l}53 \\
168 \cdot 3 \\
150 \\
178 \cdot 8\end{array}$ & $\begin{array}{l}128 \\
167 \cdot 4 \\
85 \\
182 \cdot 0\end{array}$ \\
\hline $\begin{array}{l}\text { No. of men } \\
\text { Mean diastolic B.P. } \\
\text { No. of women } \\
\text { Mean diastolic B.P. }\end{array}$ & $\begin{array}{l}\cdots \\
\ddot{*} \\
\cdots\end{array}$ & $\begin{array}{c}3 \\
(95 \cdot 0) \\
29 \\
96.4\end{array}$ & $\begin{array}{c}53 \\
94.6 \\
150 \\
99.4\end{array}$ & $\begin{array}{l}128 \\
90 \cdot 6 \\
85 \\
99 \cdot 5\end{array}$ \\
\hline
\end{tabular}

systolic and diastolic blood pressures in the different grades of arteriosclerosis. Of the women with systolic blood pressures of $160 \mathrm{~mm}$. $\mathrm{Hg}$ or above, $33 \%$ had marked arteriosclerosis, compared with $29 \%$ in those with pressures below $160 \mathrm{~mm}$. Hg. For men the respective percentages were 71 and 68. While the clinical assessment of arteriosclerosis is not very satisfactory, it may be noted that these findings are in conformity with those of various authors who, like Schaaf (1950), regard arteriosclerosis and essential hypertension as primary and independent processes. The fact that marked arteriosclerosis was commoner in the men and hypertension commoner in the women also suggests that the two conditions are not closely associated. Gavey (1949) found no relationship between the height of the blood pressure and arteriosclerosis in the various clinically accessible arteries in his series of old people. Firstbrook (1951), on the other hand, quoting Wilens (1947), states that "severe atherosclerosis is about twice as common in hypertension as in non-hypertension of the same age, sex, and adiposity." Russek (1943) also thought that arteriosclerosis was related to systolic hypertension. 


\section{Hypertension and Size of Heart}

Chest radiography was carried out in 332 subjects (143 males and 189 females). There was no significant association between the systolic or diastolic blood pressure and the size of the heart estimated from a chest radiograph taken at a distance of 6 feet ( 1.8 metres). Two independent criteria were used : First, the opinion of the radiologist (J. L. A. G.) on inspecion of the film, and, secondly, the cardio-thoracic ratio (the maximum width of the heart shadow divided by the external width of the bony thorax at that level).

Application of the $x^{2}$ test to the results, shown in Table IX, indicated that enlargement of the heart was not diagnosed by the radiologist significantly more often in those with

TABlE IX.-Size of Heart (Assessed by Radiologist) and Blood Pressure

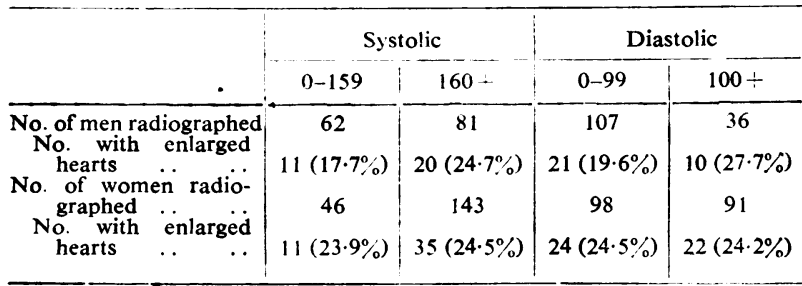

high blood pressures than in those with low ones. Also the correlation coefficients between the cardio-thoracic ratios and both systolic and diastolic blood pressures were not significant at the $5 \%$ level.

While the numbers are too small to justify a firm conclusion they suggest that hypertension by itself is not an important cause of cardiac enlargement in the elderly.

\section{Hypertension and Fitness}

At the end of the examination the subject was asked whether he considered himself fit, moderately fit, or unfit (Table X). The proportion of those in the high-bloodpressure and low-blood-pressure groups who considered themselves fit did not differ significantly.

TABle X.-Subjects' Self-assessment of Fitness by Blood Pressure

\begin{tabular}{|c|c|c|c|c|}
\hline & \multicolumn{2}{|c|}{ Systolic } & \multicolumn{2}{|c|}{ Diastólic* } \\
\hline & $0-179$ & $180+$ & $0-99$ & $100+$ \\
\hline $\begin{array}{l}\text { No. of males in group. } \\
\text { No. "fit" } \\
\text { No. of females in group } \\
\text { No. "fit" }\end{array}$ & $\begin{array}{c}120 \\
75(62 \cdot 5 \%) \\
131 \\
67(57 \%)\end{array}$ & $\begin{array}{c}67 \\
38(57 \%) \\
138 \\
60(43 \cdot 5 \%)\end{array}$ & $\begin{array}{c}132 \\
80(60 \cdot 6 \%) \\
140 \\
70(50 \%)\end{array}$ & $\begin{array}{c}53 \\
33(62 \%) \\
129 \\
57(44 \%)\end{array}$ \\
\hline
\end{tabular}

* In two cases diastolic pressure not recorded.

The $x^{2}$ test showed that the differences were not significant at the $5 \%$ level of probability.

It seems, therefore, that in this age group there is little association between feeling of fitness and the height of the blood pressure. A further assessment of the relation between hypertension and general health was made by examining the relationship between the blood pressure and the activity of the subject grouped under four headings : (a) unlimited outdoor activity; $(b)$ limited outdoor activity; (c) confined to the house; and $(d)$ bedfast. There was no correlation between degree of activity assessed in this way and systolic or diastolic blood pressure.

Correlation Coefficients Between Activity and Blood Pressure

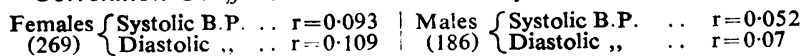

\section{Summary}

Clinical examination was made of 192 men and 284 women over pensionable age and living at home in Sheffield. Chest radiography was carried out in 332 who came to hospital for the purpose.
The relationship between resting systolic and diastolic blood pressure and the presence of certain symptoms and signs was examined.

There was no significant correlation between the height of the systolic or diastolic blood pressure and vertigo, tinnitus, angina of effort, clinically detectable arteriosclerosis, radiological size of the heart, or the subject's well-being and activity.

We would like to thank Professor W. Hobson for his helpful advice and criticism, Sister A. Lomas and Mr. A. L. Watson for carrying out the radiography, and the elderly people themselves for their willingness in submitting to a lengthy and sometimes fatiguing examination.

\section{REFERENCES}

Bell, E. T., and Clawson, B. J. (1928). Arch. Path., 5, 939 Blackford, J. M.. Bowers, J. M., and Baket, J. W. (1930). J. Amer. med. A ss., 94, 328

Boas. E. P. (1950), Geriatrics, 5,85.

Firstbrook, J. B. (1951), British Medical Journal, 2. 133.

Gavey, C. J. (1949), Lancet, 2, 725.

Greenlees, A and Adams. J. (1950). Old People in Sheffield. Shefficld.

Howell, T. H. (1942). Brit. Heart J., 4. 143.

- (1950). Old Age. London.

Master. A. M., Marks. H. H., and Dack, S (1943). J. Amer. med. Ass. 12i, 1251 .

Russek, H. I. (1943). Amer. Heart J., 26, 11.

Schaaf, R. S. (1950). Arch. intern. Med., 86, 87

Sheldon. J H. (1948). The Social Medicine of Old Age. London.

W'ilens, S. L. (1947). Arch. intern. Med., 79, 129.

\section{A SIMPLIFIED BENZIDINE TEST WITH AN EVALUATION OF SOME FAECAL OCCULT BLOOD TESTS}

BY

ANEURIN HUGHES, M.B., M.R.C.P.Ed.

Late Tutor in Medicine, University of St. Andrews, Maryfield Hospital, Dundee

An ideal test for faecal occult blood should satisfy two criteria ; (a) absolute specificity for blood or its derivatives, and, furthermore, for blood released in the alimentary canal only, as distinct from ingested blood; and (b) ease of performance. Unfortunately, no such test has been devised. The four main methods employed are:

I. Microscopical demonstration of red blood cells (Bloem, 1933).

II. Microscopical demonstration of crystals of a haemoglobin derivative-for example, Teichmann's (1853) haemin test, pyridine-haemochromogen (Kerr and Mason, 1926).

III. Spectroscopic tests demonstrating the presence of haemoglobin or its derivatives (Ryffel and Payne, 1923; Snapper and van Creveld, 1927a, 1927b; Bloem, 1933).

IV. Tests depending upon the power of haemoglobin and its derivatives to oxidize certain chromogenic substances: guaiacum, first performed by Schoenbein (1856) and verified by Day (1867), Kastle (1909), also Weber (1893), and Boas $(1901,1914)$; guaiaconic acid (Schaer, 1898); aloin (Schaer, 1900); benzidine (Schlesinger and Holst, 1906; Schumm, 1907) ; malachite green (Buckmaster, 1908); phenolphthalin (Meyer, 1903 ; Kastle and Amoss, 1906 ; Kastle, 1909) : orthotolidin (Ruttan and Hardisty, 1912a, 1912b; Kirschen et al., 1942); and other substances.

Compared with the ideal test, methods I and II satisfy neither criterion. Microscopical demonstration of red blood cells suffers from an additional disadvantage in that bleeding from high up in the alimentary canal cannot be demonstrated, since digestion of the red cells occurs. Further, as Bloem (1933) showed by comparative tests on blood-faeces mixtures, it is only about one-hundredth as sensitive as the benzidine test. Methods II and III are laborious and not practicable outside a laboratory. Bloem found spectroscopy to be 